\title{
TIME TO TAKE ACTION
}

\section{The 2006/07 crime statistics}

Dr Johan Burger, Crime and Justice Programme

Institute for Security Studies

jburger@issafrica.org

With increases of $\mathbf{2 . 4 \%}$ and $\mathbf{4 . 6 \%}$ respectively in the murder and aggravated robbery rates, the police's release of the 2006/07 crime statistics confirmed the fears of many that violent crime is on the increase. During the media conference the police communicated the bad news badly in an obvious attempt to downplay the seriousness of a situation over which they, according to their own admission, actually have very little control. In a bizarre way this confirms that whatever we are doing to fight crime isn't working and that it is time to consider something completely different.

W hen the South African Police Service (SAPS) released the latest crime statistics, they confirmed what many people expected - that there had been a serious increase in violent crime. This upward trend was disappointing, particularly in view of promising decreases since $2002 / 03$. The news led to renewed calls in the media for the Minister of Safety and Security and the National Commissioner of the SAPS to be 'fired' (e.g.in The Citizen 2007:12). The statistics also gave ammunition to those who doubt South Africa's ability to provide adequate levels of security during the 2010 Soccer World Cup. But, above all, the statistics had a negative impact on public perceptions of crime and, according to a recent Markinor survey, the police's ability to protect civilians and their property (Harris \& Radealli 2007).

The analysis in this article focuses primarily on murder and aggravated robbery and draws on international experience to contextualise the trends revealed in the SAPS statistics.

\section{The overall crime picture}

In South Africa crime and crime statistics remain highly controversial and contested issues. No explanation will ever satisfy everyone. In a country with undeniably high levels of crime, strong public reaction is understandable and more so after a particularly bad year such as 2006/07. Even the 'good' news, that there is an overall downward trend, was met with scepticism and suspicion. This is also not a uniquely South African phenomenon. In the 2005/06 British Crime Survey (BCS), for example, it was found that:

[d]espite the total number of crimes estimated by the BCS falling over recent years, comparatively high proportions of people continue to believe that crime has risen across the country as a whole and in their local area. (Walkeret al 2006:34)

Based on South Africa's crime figures for the thirteen-year period between 1994/95 and 2006/07 (Figure 1), ${ }^{1}$ it is evident that South Africa's worst levels of crime were experienced in 2002/03. These figures, incidentally, only refer to crimes that are 
reported to the police. Yet, ironically, in 2003 South Africa hosted an incident-free ICC Cricket World Cup, ${ }^{2}$ which shows that crime on its own is not a fair criterion to judge the police's ability to provide adequate security for a major event such as the 2010 Soccer World Cup. In 2002/03 a total of 2629137 crimes (in the category of most serious crimes) were reported to the police, compared to 2125227 in 2006/07. That is a decrease of almost $20 \%$. The graph in Figure 1 shows that the overall crime rate dropped steadily by approximately $6 \%$ per year between 2002/03 and 2005/06, but in $2006 / 07$ the decrease slowed to only $2 \%$.

Judging from the overall picture, at least as far as reported crime is concerned, crime is still on the decrease, albeit at a slower rate than in the three preceding years. This raises legitimate questions about why the rate of decrease has slowed. Indeed, although the crime statistics provided by the SAPS are generally regarded as fairly accurate and credible, the question of the extent to which reported crime is a true reflection of the 'real' crime situation remains relevant. For example, according to Burton et al (2004:105-108), the $2003 \mathrm{~N}$ ational Victims of Crime Survey in South Africa showed a reporting rate of $97 \%$ for vehicle theft, but a reporting rate of only $29 \%$ for robbery (Figure 2 ). More regular 'victims of crime' surveys, such as those conducted by the Home O ffice in Britain on an annual basis, would go some way towards providing an indication of what percentage of crime is reported to the police.

But it is undoubtedly the violence associated with crime in South Africa that has had the most negative impact on perceptions of crime and the vulnerability expressed by many. Accordingly, the following six violent crimes and crime tendencies (i.e. murder and five types of aggravated robbery: house robbery, business robbery, bank robbery, cash-in-transit robbery and car-hijackings) will be briefly discussed.

\section{Violent crime trends}

Murder and aggravated robbery are the two violent crimes that, after consecutive years in which the statistics revealed a steady decrease in the rate of incidence, again showed an upward curve in the 2006/07 period. According to the police (SAPS 2007:11) much of the increase in robbery in particular can be linked to the security guard strike of April - June 2006 '... which left a void for robbers ... to commit crime'. In turn, aggravated robbery would also have an impact on the murder rate, because murder and attempted murder often accompany these robberies.

Murder

In the eleven-year period between 1994/95 and $2005 / 06$, the murder rate decreased by approximately $41 \%$ from 67 per 100000 to 39.5 (Figure 3). Twice before, in 1995/06 and 1998/99,

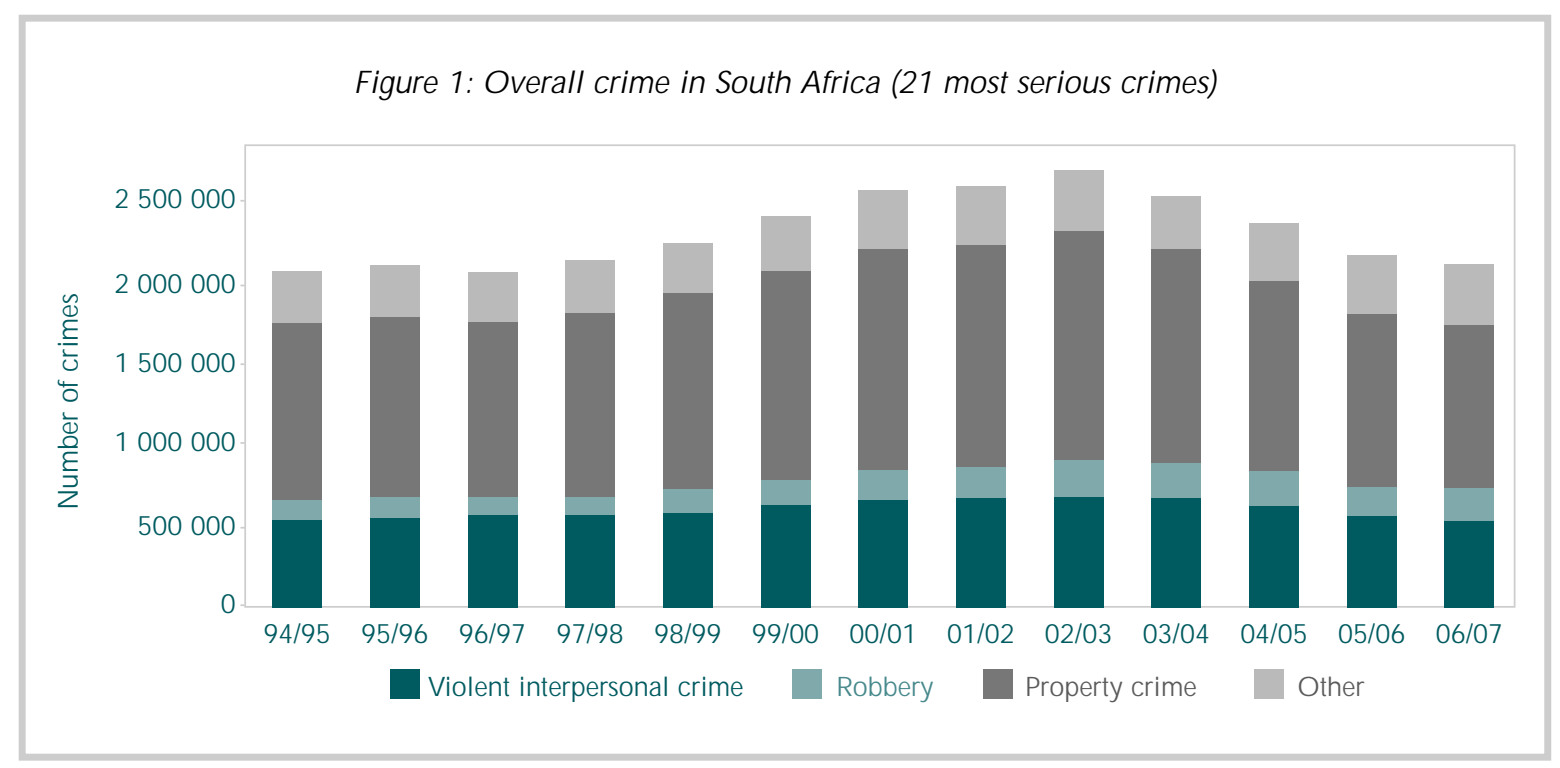


Figure 2: Reporting of crime to police

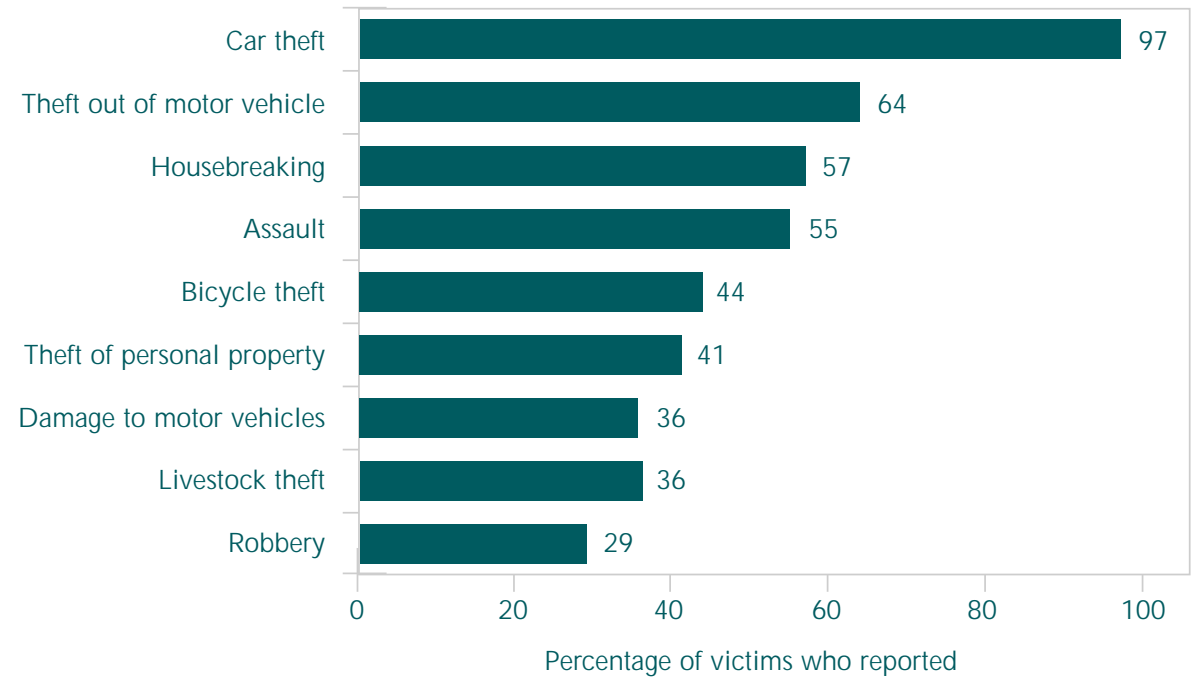

the murder rate showed slight increases followed again by consecutive years of decline. In 2006/07 the rate increased once again to 40.5 . It is impossible to say whether this is just another periodical increase to be followed by a renewed downward trend or whether this is indicative of a new rise in violent crime in this country.

Claims by the police that most murders and other 'social contact crimes' take place between people who know each other is often met with disbelief and regarded as an excuse for not providing the public with the security they believe they are entitled to. For example, in their 2006/07 crime report the SAPS indicated that a docket analysis showed that in $81,5 \%$ of murder cases the perpetrators were known to their victims; in $61,9 \%$ of cases perpetrators were either relatives, friends or acquaintances of victims; and in $20,1 \%$ of cases perpetrators were relatives (SAPS 2007:28). According to the police, the relatively high number of contact crimes occur in social environments (e.g. residences), which are normally outside the reach of conventional policing (SAPS 2007:4). This means

that there is very little, if anything, the police can do to prevent these particular types of crime.

This too is not a uniquely South African phenomenon. For example, a study in Australia found a clear relationship in many homicide cases between victims and offenders (Australian Institute of Criminology 2006:20). The study found that $38 \%$ of male 
and $10 \%$ of female victims were likely to be killed by a friend or an acquaintance; $59 \%$ of female and $9 \%$ of male victims were likely to be killed by an intimate partner; $17 \%$ and $18 \%$ of male and female victims respectively were likely to be killed by a family member; and only $2 \%$ of female victims are killed by an unknown person, compared to $25 \%$ of male victims.

This analysis supports the argument that the ability of the police to impact on 'social contact crimes' such as murder is more limited than the public generally realises. The only real proactive contribution the police can make in this regard is by creating a credible deterrent through effective and efficient investigations (the creation of a belief or certainty in the minds of potential criminals that they will be caught).

\section{Aggravated robbery}

Apart from murder and rape, aggravated robbery, certainly because of its nature and the violence or threat of violence associated with it, currently seems to be the most feared crime in this country. As shown in Figure 4, aggravated robbery peaked in 2003/04 at 288 per 100000 after consecutive annual increases from 164 in 1996/97. In real terms this amounts to almost 134000 robberies compared to 'only' 76 000, seven years before. In 2004/05 and $2005 / 06$ the aggravated robbery rate (per
100 000) decreased to 272.2 and 255.3 respectively. Although the rate was still much higher than the 1996/97 figure, these decreases were promising and raised expectations that aggravated robbery was on the decline. However, in 2006/07 the rate of aggravated robberies increased again (with 4,6\%) to 267.1 per 100000 or, in real terms, 126558 incidents.

The real threat or perceived threat of aggravated robbery is better understood when it is disaggregated into some of its sub-categories. The following serve as examples:

- Residential or house robberies increased by $25,4 \%$ in the last year from 10173 to 12761 incidents. These incidents have in fact been increasing over consecutive years since they were first indicated as a separate crime category in $2002 / 03$. This type of crime has a very negative impact on an individual's feelings of safety and general perceptions of crime. Everyone would like to believe that their home is their sanctuary where they and their family are safe. According to the crime figures, the risk of having this sanctuary invaded by criminals is on the increase. In addition, this 'invasion' is often accompanied by assault and even torture, rape and murder. Criminals use torture as a means to achieve compliance and to access the victim's safe and PIN numbers, etc.

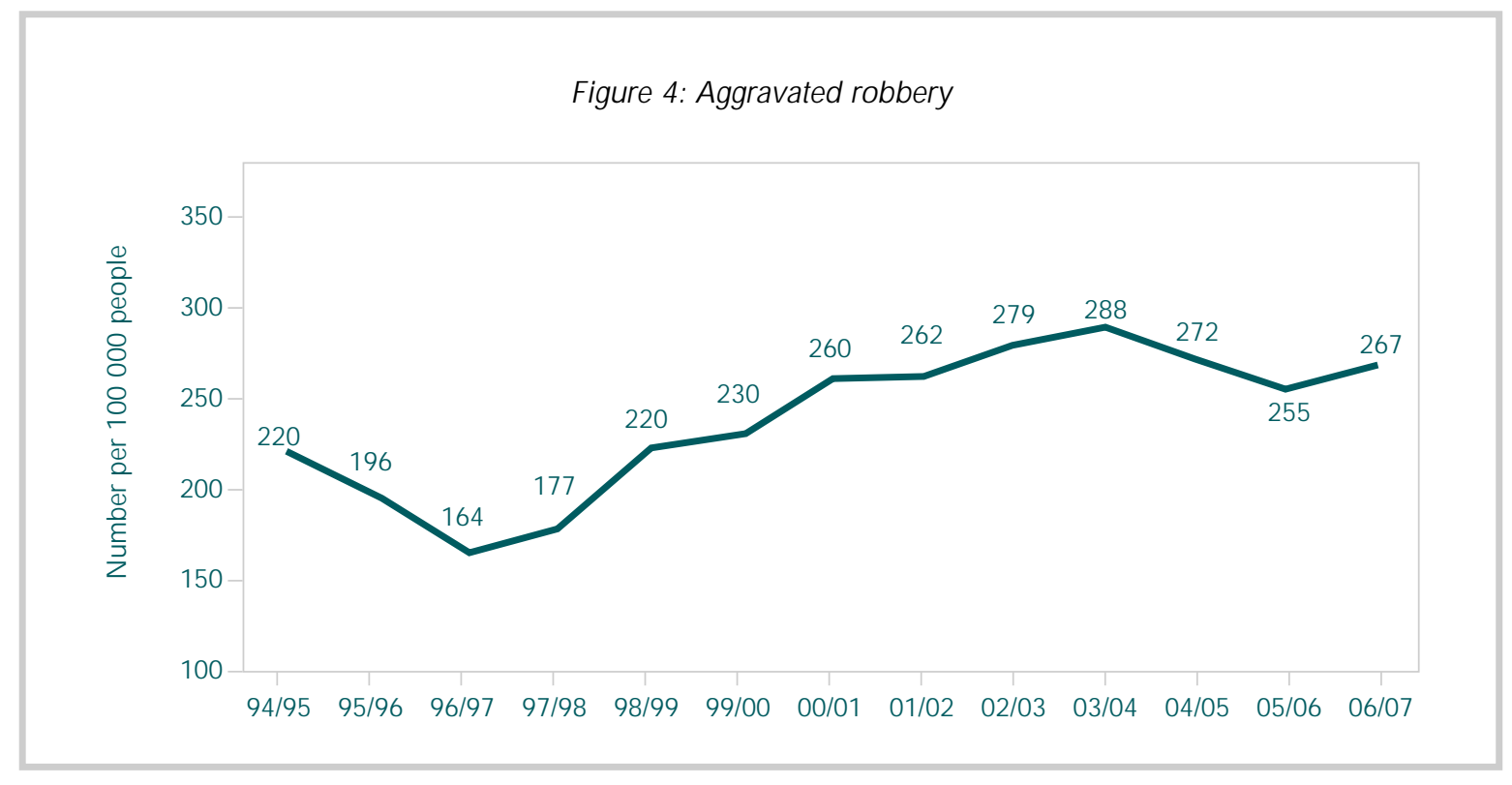


- Car hijackings have increased since 2004/05, from 12434 to 13599 incidents, an increase of $6 \%$ in $2006 / 07$. This type of crime exacerbates the fear experienced by most people. Fear is becoming the common denominator in the public perception of crime in this country. There is a growing perception that not only are people no longer safe in their own homes, but they face the constant threat of being hijacked, for example between home and workplace or during an evening out.

- To make matters worse, business robberies increased with $52,2 \%$ in the last year. This is an increase from 3320 incidents in 2004/2005 to 6689 in 2006/07. This too has a negative impact on public perceptions, for many of these crimes happen at shopping centres and restaurants.

- In addition, bank robberies increased by $118,6 \%$ from 59 to 129 incidents. This crime type is again on the increase since 2003/04, after impressive decreases from the 561 recorded in 1996/97.

- Cash-in-transit robberies increased by $21,9 \%$ from 383 to 467 incidents. This crime type is also on the increase since 2003/04, when 192 incidents were recorded.

The reason why criminals in many cases shoot and kill their victims even after they completed the initial crime (e.g. robbery), remains a contentious and unresolved phenomenon. However, it is informative to know that this phenomenon has also been observed elsewhere. In a report by the Police Executive Research Forum (2006:6-7) it was found, based on the crime figures for the U nited States, that not only was robbery becoming more prevalent, but also more deadly. As one of the police chiefs observed:

... a disturbing aspect in a number of robberies was that upon completion of the robbery the victim was shot anyway.

\section{Conclusion}

The main message from these figures is clear: whatever we as a country (not just the police) are doing to fight crime, is not working. It shows us that there is something seriously wrong with our approach to this 'fight' and the way in which we present our crime situation. The release of this year's statistics was again overshadowed by explanations of why our crime is not as bad as it appears to be. In an apparent attempt to underplay the gravity of the situation, the release was accompanied by remarks such as: 'It's not a train smash' and, in reference to the possible impact of crime on the 2010 Soccer World Cup, 'I do not miss any sleep over it'.

For some reason the police allow themselves to be blamed for the failures of government departments across the board and for the manifestations of a morally sick society. At the annual release of the crime figures, the police, unfairly so, are alone in the 'dock'. They are expected not only to tell us what our crime situation is, but also why it is good or bad and what they are doing about it. Of course the police do not help their cause by downplaying the seriousness of the situation. However, what we need when crime statistics are released are the other representatives of government, such as the D epartments of Justice, Correctional Services, Housing, Labour, Provincial and Local Government, Welfare, to also tell us what they are doing to address crime and the conditions conducive to crime.

To enable a more fair and sensible distribution of responsibility for crime fighting, we need an integrated national strategy. Such a strategy should direct all available government resources on a massive scale to achieving realistic objectives. An integrated national strategy of this kind will only be possible if it is preceded by a comprehensive national inquiry, e.g. by a commission of inquiry, to determine the extent of our crime, where it happens, why it happens, and why it is so violent. The commission (or its alternative) should also be mandated to determine what needs to be done, and by whom. The allocation of tasks will have to be realistic; both as far as the tasking of the right people (government departments and other role players) and the setting of achievable targets are concerned. Such a massive and all-out national campaign to fight crime is not only a precondition for success, but will only work if it is controlled by an overarching national coordinating structure with the overriding authority to direct all government departments, and not just the criminal justice system. The National Security Council (NSC) may 
be just such a structure, but changes to its mandate, structure and functioning would be required. ${ }^{3}$

Criticism about the way in which crime is being dealt with in this country should not be construed as if it is just another uniquely South African phenomenon. In 1997 George Kelling and Catherine Coles, in their book Fixing Broken Windows: Restoring O rder and Reducing Crime in our Communities (1997:1) were highly critical of the criminal justice approach to crime fighting in the United States at the time:

With fear of crime at all-time high levels, our national political leaders propose dramatic solutions to the 'crime problem'. They focus on ... incarceration policies, construction of more prisons, tighter gun control, and increasing the number of police on the streets.

Mr. Kenneth Baker, British Home Secretary in the Thatcher government, in his memoirs in 1990, demonstrated a similar lack of political understanding of the complexities of crime (Morgan \& Newburn 1997:2-3):

... while several of my ministerial colleagues and Tory MP's supported the police in public, they were highly critical of them in private. There was impatience, if not anger, that although we had spent $87 \%$ more in real terms since 1979, and had increased police numbers by 27000 , there had still been a substantial increase in crime.

In the last six years the SAPS numbers increased with approximately 40000 and their budget almost doubled from R17 billion to R32 billion. This gives us a police/public ratio of approximately 1:370, which is already better than the $\mathrm{UN}$ guideline of 1:400. This situation is set to improve even further with more than 30000 police officials to be added over the next three years to reach a target of 192000 by 2010 . We are, therefore, entitled to expect the police and the rest of the criminal justice system to be more effective and efficient in terms of what they are, or should be, capable of. We know from international research that the police do not prevent crime; at best they can act as a deterrent to crime in places where they (the police) are present.
This means our police need to become more visible. A visible police presence goes a long way to reassuring a fearful public. Police investigations should also be motivated by the desire to engender a realistic fear in the minds of criminals or wouldbe criminals that they will be caught. For optimal deterrence, good investigations should be followed by well-prepared prosecutions, and a prison system that can accommodate those who receive prison sentences (and keep them there). Considering its prevailing weaknesses it is clear that our criminal justice system is currently not able to meet all of these challenges. ${ }^{4}$

In this regard, and to the extent that the police can reduce crime, the crime statistics do raise pertinent questions, for example:

- What was (is) the impact of the ongoing restructuring process on the police's ability to combat crime?

- There are renewed calls for more community involvement in the fight against crime, but why is it taking the police such a long time (since 1998) to finalise (approve) its policy/national instruction on sector policing - a practical policing concept that was developed specifically to enhance police-community cooperation?

- How can the police set themselves a target of decreasing contact crimes by $7-10 \%$ per year when they argue, convincingly, that they do not control the socio-economic causes and conditions that underlie crime?

Finally, in their report on the 2006/07 crime statistics, the police refer to the 'mistaken' comparison by 'analysts' who, for example, put South Africa's murder rate at approximately eight times that of the international norm. This analyst, for one, agrees with the police's argument that international comparisons, for a variety of reasons, are highly problematic, but, like the police, we believe that 'very broad and rough comparison[s]' sometimes help to determine more or less where we stand in the international arena. Unsurprisingly, the police themselves declare (SAPS 2007:3) that if South Africa can reduce its contact crimes by 7-10\% per year for consecutive years it will take us at least another ten years to reach the levels of the majority of Interpol countries. 


\section{References}

Australian Institute of Criminology 2006. Australian Crime: Facts and Figures. Available at:

http://www.aic.gov.au/publications/facts/2006/. Accessed on 25 July 2006.

Burton, P, Du Plessis, A, Leggett, T, Louw, A, Mistry, D \& Van Vuuren, H 2004. National Victims of Crime Survey: South Africa 2003. Pretoria: ISS M onograph Series (101). July.

Harris, M \& Radaelli, S 2007. Paralysed by fear: Perceptions of crime and violence in South Africa. SA Crime Q uarterly (20). Pretoria: Institute for Security Studies. pp1-6.

Kelling, GL \& Coles, CM 1997. Fixing broken windows: restoring order and reducing crime in our communities. New York: Touchstone (Simon \& Schuster).

Louw, A 2006. The start of a 'crime wave'?: The 2005/06 official crime statistics in context. SA Crime Q uarterly (18). Pretoria: Institute for Security Studies. pp1-8.

Morgan, R \& N ewburn, T 1997. The future of policing. Oxford: Clarendon Press.

Police Executive Research Forum 2006. A gathering storm: Violent crime in America. 0 ctober. Available at: www.PoliceForum.org. Accessed on 18 July 2007.

SAPS 2004. Annual Report of the South African Police Service 2003/2004. Department of Safety and Security. Pretoria: Government Printer.

SAPS 2007. South African Police Service. Crime in the RSA for A pril to March 2001/2002 to 2006/2007. Available at: www.saps.gov.za. Accessed on 3 June 2007.

The Citizen 2007. Score against crime for 2010, 5 July.

Walker, A, Kershaw, C \& Nicholas, S 2006. Crime in England and Wales 2005/06. July. Available at: http://www.homeoffice.gov.uk/rds/index.htm. Accessed on 18 July 2007.

\section{Endnotes}

1 All the graphs (crime rates) and the South African crime figures used in this article are based on information taken from the Annual Report of the SAPS 2003/2004 (SAPS 2004:19), as well as the SAPS's crime report for $2001 / 2002$ to $2006 / 2007$ (SAPS 2007:1, 7-8). The graphs are also an updated version of those used by Antoinette Louw (2006:2,4-5).

2 See Johan Burger 2007. A Golden Goal for South Africa: Security Arrangements for the 2010 FIFA Soccer World Cup. SA Crime Q uarterly (19). Pretoria: Institute for Security Studies. pp1-6.

3 For an in-depth discussion of a national strategy to fight crime, see Burger, J 2007. Strategic Perspectives on
Crime and Policing in South Africa. Pretoria: Van Schaik Publishers.

4 See for example the discussion on some of these weaknesses by Altbeker, A. 'H ow we got it wrong: What to do about the failure of crime prevention', in this edition of the SACQ. 